\title{
Conceptualization (vikalpa) of Other Sentient Beings in the Early Yogācāra Texts
}

\author{
TAKAHASHI Kōichi
}

As is well known, the Yogācāra, one of the Mahāyāna schools, advocates that there are no objects external to the consciousness. This philosophical standpoint is represented by the term vijñaptimātratā. Some scholars have been dealing with this notion with a philosophical interest. However, the penetration of the vijñaptimātratā is not the ultimate goal for the Yogācāra thought. Lambert Schmithausen addressed this issue in his recent work On the Problem of the External World in the Ch'eng wei shih lun. He writes:

In many early Yogācāra texts, realizing in meditative concentration that the objects we experience are nothing but mind or consciousness is only a preliminary step on the way to the awareness of the highest truth, or 'true reality' (tathat $\bar{a}$ ) .... (Schmithausen 2015, 53)

Added to that, he also indicated that realizing vijñaptimātratā is essentially connected to the benefit for sentient beings:

The level of vijñaptimātra is, however, not only a preliminary step to be surmounted, but also a plane to which Buddhas and Bodhisattvas return or re-descend, for the sake of other sentient beings. (Schmithausen 2015, 54)

From the viewpoint of Mahāyāna Buddhism, we should focus on the issue why sentient beings are suffering in life and how they can be relieved from suffering. In this sense, to ask how the external world exists or whether the objects perceived by the consciousness do actually exist or not in the external world might not be the fundamental problem. ${ }^{1)}$ The more esoteric question is how the Yogācāra treated the existence of other sentient beings defiled with afflictions or kleśa, because they regarded the universe, in which the sentient beings are included, as the mind itself. Yamabe Nobuyoshi dealt with this issue through the examination of Vasubandhu's Viṃśikā Vijñaptimātratāsiddhi. ${ }^{2)}$ According to him, the basic motif behind the Yogācāra 
philosophers' system was not theoretical but practical (Yamabe 1998, 35). In his conclusion, he suggested that it is understandable that the Yogācāra as practitioners of yoga meditation did not argue on the problem of other minds so carefully in their early texts, if their main concern was to observe their own inner world (Yamabe 1998, 38). As far as Vasubandhu's opinion, Yamabe's interpretation is agreeable. However, what Schmithausen pointed out also seems to be an important and profound issue for scholars investigating the Yogācāra thought. This short essay attempts to present some testimonies to support Schmithausen's indication, because he did not show any proof to argue on this issue.

\section{Process of Yogācāra Practice, and Instruction of Sentient Beings}

Schmithausen does not show testimonies about the position of vijñaptimātratā in the practical system of Yogācāra, but the Cheng weishi lun 成唯識論 mentions it in the explanation of the fivefold steps of yoga practice.

How does [the Bodhisattva] gradually penetrate vijñaptimātratā? It is said that the Bodhisattva is deeply confident of the phase and essence of consciousness in the step of equipment [for enlightenment] (*sambhära). In the step of practice (* prayoga), [he] gradually removes [both] objects and subjects or *grāhya and *grähaka, [and then] develops the real viewing. In the step of achievement [he] achieves in accordance with reality. In the step of the meditation (*bhāvanā), according to the reality perceived [by him] [he] frequently practices [meditation], and removes the other obstacles. Accomplishing the step of the ultimate $\left({ }^{*}\right.$ nisțhā), [he] escapes from the obstacles [and becomes] perfect. Till the end of the future, [he] instructs the sentient beings, and make [them] penetrate the phase and essence of the viñaptimātrata. ${ }^{3)}$

According to that, the Bodhisattva comprehends the vijñaptimātratā in the second step corresponding to the prayogamarga, in which he rejects the image of objects and subjects appearing in his own consciousness. The penetration of vijñaptimātratā, however, is not yet completed at this step. The Bodhisattva has to repeatedly practice on it until the final step. In addition, he is required to introduce other sentient beings to the doctrine of vijñaptimätratā. In the Cheng weishi lun, it is not explicit whether the Bodhisattva should begin the instruction after entering the third step or accomplishing the final step, but it is noteworthy that the Cheng weishi lun presupposes the existence of sentient beings who are ignorant on vijñaptimātratā and to be guided by the Bodhisattva. This paragraph in the Cheng weishi lun seems to indicate the two aspects of 
Bodhisattva's activity relating to the notion vijñaptimātratā. One is the meditative practice directed to the inside of his mind: the other is the instruction of other people. It means that the enlightenment of the vijñaptimātratā of the Bodhisattva himself does not directly and mechanically lead ordinary people to reform their thinking.

\section{Realizing the vijñaptimātratā and Ethical Practice in the Mahāyānasamgraha}

In his Mahāyānasamgraha, Asanga also deals with the fivefold steps of yoga practice in relation to the ten stages of Bodhisattva, i.e., bodhisattvabhūmi. In chapter 3 of this text, he states that the Bodhisattva who has recognized the vijñaptimātratā enters the pramuditäbhümi which is the first stage of the ten stages of Bodhisattva. As he explains, the pramuditābhūmi corresponds to the course of seeing or darśanamärga which is identical with the step of achievement mentioned as the third step in the fivefold steps of yoga practice in the Cheng weishi lun. In this stage, the Bodhisattva attains the nondiscrimination of all sentient beings from himself. Asanga said as follows:

Thus, the Bodhisattva penetrates into the manifested aspect of [objects] to be known (*jñeya) by penetrating into the vijñaptimātratā. He attains the stage of delight (* pramuditābhūmi) because of penetrating it (vijñaptimātratā). He correctly comprehends "the essence of dharma" (*dharmadhātu), is born in the family of the Tathāgata, attains the nondiscrimination of all sentient beings [from hiself], the nondiscrimination of all bodhisattvas [from himself], and the nondiscrimination of all Buddhas [from himself]. It is the course of seeing (*darśanamārga) for him. ${ }^{4)}$

Chapter 4 of this work deals with the sixfold perfections or pāramitās. In his annotated translation of this text, Nagao Gajin indicated that the first three chapters of the Mahāyānasamgraha focus on the inner experience of the Bodhisattva, but after chapter 4, Asanga describes social activity like the sixfold pāramitās in detail. ${ }^{5)}$ The Mahāyānasamgraha arguably considers the penetration of the vijñaptimātratā to be the foundation of ethical practice of the Bodhisattva. It implies that the realization of vijñaptimātratā cannot contradict the existence of sentient beings.

\section{Existence of Other Sentient Beings in the Epistemological Context}

In the Mahāyannasamgraha, the existence of other sentient beings is also mentioned in the explanation of the four aspects of alayavijñana. Then it is considered that the other beings are demanded not only in the ethical context but also from the epistemological 
viewpoint. According to the Mahāyannasamgraha, the ālayavijñanna has common and uncommon aspects. These two are respectively corresponding to seeds of the surrounding world regarded as insentient things, and those of the individual supports or *āyatanas with feelings. ${ }^{6}$ The counteractive or *pratipakșa acquired in a yoga meditation can make the individual support of the meditator disappear and purify his mind's eye. In this state, however, the common aspect perceived by others' conceptualization still remains. ${ }^{7)}$ The meditator with the purified mind's eye perceives the pure realm of the Buddha, but the same thing could be recognized as a place with a pile of rubble by ordinary people. The theory to explain why the world remains is notable. It is not because there is an external world, but because the others' conceptualization or *vikalpa functions to raise the surrounding world. ${ }^{8)}$

A similar statement can be found in the Viniścayasamgrahaṇi of the Yogācārabhümi. In the section dealing with the five vastu theory, an opponent asks why all entities including both sentient beings and insentient things could not be refused by means of the insight attained by a superior person. In the five vastu theory, the sentient beings and insentient things are categorized in the image or *nimitta which is produced from conceptualization or *vikalpa. The insight of a superior person could be acquired by stopping the activity of conceptualization in order to remove the *nimitta. Thus, someone's achievement of the superior insight should result in the extinction of all *nimittas even for other people. But actually, such extinction does not happen. The Viniścayasamgrahani explains about the reason for that as follows:

When [something] arising from the cause of an uncommon conceptualization is not conceptualized [by one perception of a superior person], it is terminated. When [something] arising from a common conceptualization is not conceptualized [by one perception of a superior person], it is not terminated, because it is fixed by other's conceptualization. Otherwise, other's conceptualization would not have any significance. Even though it [i.e., the entity produced by other's conceptualization] does not cease, it should be comprehended that the insight of [a person] equipped with the pure nature is purified. ${ }^{9}$

The Viniścayasamgrahani does not clarify what is represented by "something originated from a common conceptualization," but from the context, it could be understood as all entities including both sentient beings and insentient things mentioned in the opponent's question. These two do not vanish when someone attains the superior 
insight, because they are cognized by others' conceptualization. Instead of that, the insight of a meditator could be purified. The point of the Viniścayasamgrahanī is evidently parallel to that of the Mahāyannasamgraha. ${ }^{10)}$

\section{Conclusion}

These passages seem to mean that the same object could be recognized in various ways, when they are seen from different viewpoints. One might think that these works inadvertently stray from the mind only theory into the existence of the external world. However, their expressions arguably have a delicate nuance. They simply indicate that the reason why all entities are not disappear is that the conceptualization of other sentient beings continues functioning. In other words, the conceptualization of other sentient beings sustains the world contaminated with images. It means that the conceptualization must precede the existence of all entities appearing as sentient beings and insentient things.

It might be more informative to investigate the significance with regard to the existence of other sentient beings than to ask whether the external world actually exists or not, when we study Yogācāra philosophy.

\section{Notes}

1) See Schmithausen 2015, 50: "At least for most forms of Buddhism, it would seem appropriate to state that their central concern is with sentient beings, more precisely: with their suffering ... and its causes, viz. spiritual defilements . . . and karma, as well as with their liberation from suffering and attainment of spiritual peace or true happiness through the elimination or replacement of those causes. In Mahāyāna Buddhism, the concern is, more explicitly, not only with one's own suffering but also, and even mainly, with the suffering of other sentient beings."

2) See Yamabe 1998, 5: "The idealist philosophy of the Yogācāra tradition presents many theoretical problems in terms of the relationship between "self" and "other." If everything in the world is merely a projection of our own mind, can the minds of other people exist? If they do exist, and if each person's mind creates a distinct world, how can many people perceive the "same external" object simultaneously? If one person perceives a change in the "external" world, do other people recognize the same change?"

3) Cheng weishi lun, 48b15-20 云何漸次悟入唯識. 謂諸菩薩於識相性, 資糧位中能深信解. 在加行位, 能漸伏除所取能取, 引発真見. 在通達位, 如実通達. 修習位中, 如所見理, 数 数修習, 伏断余障. 至究竟位, 出障円明. 能尽未来, 化有情類, 復令悟入唯識相性.

4) See Nagao 1987, III.11 (text): de ltar na byang chub sems dpa' 'di shes bya'i mtshan nyid la rnam par 
rig pa tsam nyid du 'jug pas zhugs pa yin te/ der zhugs pas sa rab tu dga' ba la zhugs pa yin te/ chos kyi dbyings legs par rtogs pa yin/ de bzhin gzhegs pa'i rigs su skyes pa yin/ sems can thams cad la sems mnyam pa dang/ byang chub sems dpa'i thams cad la sems mnyam pa dang/ sangs rgyas thams cad la sems mnyam pa thob pa yin te/ de ni de'i mthong ba'i lam yin no//

5) See Nagao 1987, 106-107: “This chapter deals with the sixfold pāramitās or perfections, which function as the cause of the penetration into the mind-only and also represent the result of itself. In other words, the previous chapter indicates the penetration from the viewpoints of the mental attitude and investigation concerning to the inward personal experience; this chapter deals with the outward social activities, which appear as the sixfold perfections beginning with donation, as the virtue of bodhisattvas' discipline."

6) See Nagao 1982, I. 60 (text): thun mong ni snod kyi 'jig rten gyi sa bon gang yin pa'o// thun mong ma yin pa de ni so sor rang gi skye mched kyi sa bon gang yin pa'o// thun mong gang yin pa de ni tshor ba med pa 'byung ba'i sa bon no// thun mong ma yin pa gang yin pa de dag ni tshor ba dang bcas pa 'byung ba'i sa bon te/ (The common [aspect] is the seed of the surrounding world. The uncommon [aspect] is the seed of individual support. That which is common is the seed to produce insentient things. Those which are uncommon are the seed[s] to produce [something] accompanied by feelings.)

7) See Nagao 1982, I. 60 (text): gnyen po byung na thun mong ma yin pa mi mthun pa'i phyogs 'gag go// thun mong pa gzhan gyi rnam par rtog pas yongs su zin pa la ni mthong pa rnam par dag par 'gyur tel rnal byor pa rnams gyi mos pa tha dad pas dngos po gcig la blta bar bya ba tha dad pa dmigs pa bzhin no// (When the counteractive arises, the uncommon [aspect that is] opposed is terminated. One's vision of the common [aspects] fixed by the other's conceptualization becomes purified. For example, [people] experience various ways of looking at one and the same object, because of the various forms of confidence of yogins.)

8) See Nagao 1982, 260-261 (annotation): "In this section, the Mahāyānasamgraha states that there are two aspects of the alayavijñanna namely the aspect common to the others and the uncommon one. Then, it explains the relationship between these two aspects and meditative practice....

The former [= the surrounding world] is expressed as "arising without feeling," namely insentient or inanimate. This aspect is shared with others as "common appearance." The latter [= the world of sentient beings] is "uncommon" to others. It is the existence of each sentient being with "feeling." What is interrupted by the meditative practice and vanishes is something cognized. As for the surrounding world, the attitude of dealing with it simply becomes purified. (This annotation is originally written in Japanese.)

9) Viniścayasamgrahanī (see Takahashi 2005: 1.12.10): rnam par rtog pa thun mong ma yin pa'i rgyu las byung ba rnam par ma brtags pa gang yin pa de ni 'gog par 'gyur la/ rnam par rtog pa thun mong ba'i rgyu las byung ba rnam par ma brtags pa gang yin pa de ni gzhan gyi rnam par rtog pas zin pa yin pas mi 'gog ste/gzhan du na gzhan gyi rnam par rtog pa don med par 'gyur ro// de ma' 'gags na yang rnam par dag pa'i bdag nyid can gyi mthong ba rnam par dag par 'gyur bar khong du chud par bya ste/ (Cf. Kramer 2005, 159) 
10) Kramer 2005, 159, n. 294: "Im MS (= Mahāyānasaṃgraha) finden sich ähnliche Erläuterungen in bezug auf das gemeinsame und individuelle ālayavijñāna... . Die Unterteilung der Vorstellung in eine gemeinsame und eine individuelle erinnert auch an die Differenzierung vom gemeinsamen und individuellen Karma." The similar issues are argued in the Cheng weishi lun. Schmithausen investigated the problem with regard to cognizing other's mind (Schmithausen 2015, 18-22). He also examined the sentence describing the common and uncommon aspects of consciousness in the Cheng weishi lun (Schmithausen 2015, 35-38). The Dharmadharmatāvibhāga also deals with the problem (Mathes 1996, 124-130).

\section{Bibliography}

\section{Primary Sources}

Cheng weishi lun 成唯識論. Taisho vol. 31, no. 1585.

Mahāyānasaṃraha. See Nagao 1982, 1987.

Viniścayasamgrahanī. See Takahashi 2005.

\section{Secondary Sources}

Kramer, Jowita. 2005. Kategorien der Wirklichkeit im frühen Yogācāra. Contribution to Tibetan Studies, vol. 4. Wiesbaden: Dr. Ludwig Reichert Verlag.

Mathes, Klaus-Dieter. 1996. Unterscheidung der Gegebenheiten von ihrem wahren Wesen (Dharmadharmatāvibhāga). Indica et Tibetica, Bd. 26. Swisttal-Odendorf: Indica et Tibetica Verlag.

Nagao Gajin 長尾雅人. 1982. Shōdaijōron wayaku to chūkai 摂大乗論 和訳と注解, jō 上. Tokyo: Kōdansha.

- 1987. Shōdaijōron wayaku to chūkai 摂大乗論 和訳と注解, ge 下. Tokyo: Kōdansha.

Schmithausen, Lambert. 2015. On the Problem of the External World in the Ch'eng wei shih lun. Studia Philologica Buddhica Occasional Paper Series XIII. Electronic Edition with Corrections and Additions. Accessed Octorber 16, 2016. http://philpapers.org/archive/SCHOTP-12.pdf. First edition published 2005. Tokyo: International Institute for Buddhist Studies.

Takahashi Kōichi 高橋晃一. 2005. Bosatsuji “Shinjitsugi-bon” kara "Shōkecchaku-bun chū Bosatsuji” e no shisō tenkai 『菩薩地』「真実義品」から「摂決択分中菩薩地」への思想展開. Bibliotheca Indologica et Buddhologica 12. Tokyo: Sankibō Busshorin.

Yamabe Nobuyoshi 山部能宜. 1998. “Self and Other in the Yogācāra Tradition.” In Nihon Bukkyō bunka ronsō: Kitabatake Tensei hakushi koki kinen ronbunshū 日本仏教文化論叢: 北畠典生博士古 稀記念論文集, jōkan 上巻, 15-41. Kyoto: Nagata Bunshōdō.

(This article was supported by JSPS KAKENHI 24520050 [Grant-in-Aid for Scientific Research (C)])

Key words Viniścayasamgrahaṇī, Mahāyānasamgraha, Cheng weishi lun, sentient beings

(Project Researcher, The University of Tokyo, PhD) 